\title{
Investigation of frxA gene mutations in metronidazole resistant Helicobacter pylori strains in Tabriz City
}

\author{
Farshid Ardabili $^{1,2}$, Reza Malekoughli ${ }^{3}$, Jalal Zaman ${ }^{2}$ \\ ${ }^{1}$ Young Researchers Club, Aligudarz Branch, Islamic Azad University, Aligudarz, Iran \\ ${ }^{2}$ Orumiyeh Military Hospital, Health Administration of Army (NEZAJA), Tehran, Iran \\ ${ }^{3} \mathrm{MSc}$, Department of Microbiology, Marand Branch, Islamic Azad University, Marand, Iran
}

\begin{abstract}
Background: Due to the high rate of Helicobacter pylori infection in our country and its treatment failure, and also because of the high prevalence of antibiotic resistance of this bacterium, evaluating causes of Helicobacter pylori resistance to metronidazole and its effect on the therapeutic course is necessary.

Materials and methods: A biopsy sample was obtained from 275 suspected patients referred to Imam Reza Hospital in Tabriz. After identification of Helicobacter pylori, bacterial suspension (4 McFarland Standard) was poured onto plates and then antibiotic discs of metronidazole and E-test were placed on it. Metronidazole-resistant strains were detected and mutations in the frxA gene were detected by PCR.

Results: Of 112 isolated strains, 85 resistant strains were identified. Resistance to metronidazole was more prevalent in women $(50 \%)$ than males $(35 \%)$. Of 85 resistant strains, 70 strains $(82.35 \%)$ had MIC $\geq 8$ in the E-test; while in the DDA, 88 strains were resistant. Of the 20 randomly selected metronidazole-resistant strains, mutation was proved in the frxA gene in 4 strains, but mutagenesis was not proved in susceptible strains.

Conclusion: Helicobacter pylori resistance to metronidazole is high in this area and the frequency of this resistance is higher in women than in men. One of the mechanism of resistance of Helicobacter pylori to metronidazole is the occurrence of a mutation in the frxA gene, but this mutation is not the only factor in developing resistance to metronidazole and the evaluation of other molecular mechanisms of resistance to metronidazole seems to be necessary.
\end{abstract}

Keywords: Helicobacter pylori, Antibiotic resistance, Metronidazole, frxA gene.

Cited as: Ardabili F, Malekoughli R, Zaman J. Investigation of frxA gene mutations in metronidazole resistant Helicobacter pylori strains in Tabriz City. Medical Science Journal of Islamic Azad University, Tehran Medical Branch 2020; 30(3): 281-286.

Correspondence to: Farshid Ardabili

Tel: +989103781468

E-mail: farshidardabili1375@gmail.com

ORCID ID: 0000-0001-8058-0655

Received: 27 Apr 2019; Accepted: 18 Mar 2020 
مجله علوم يزشكى دانشگاه آزاد اسلامى

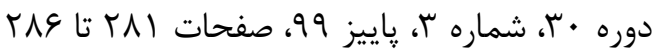

Original

Article

\title{
بررسى جهششهاى زن frXA در سويه هاى هليكوباكترييلورى مقاوم به مترونيدازول در شهرستان تبريز
}

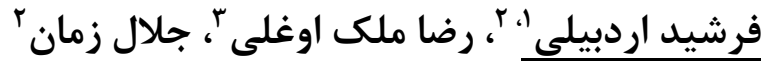

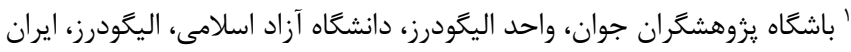

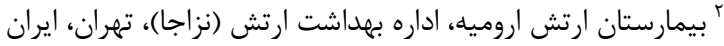

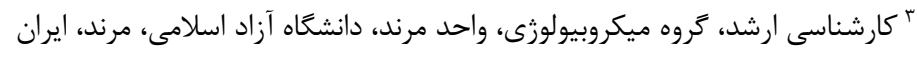
جـكنه

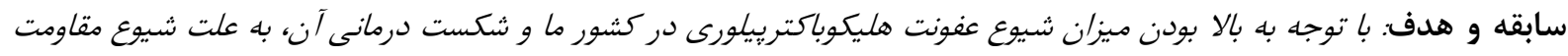

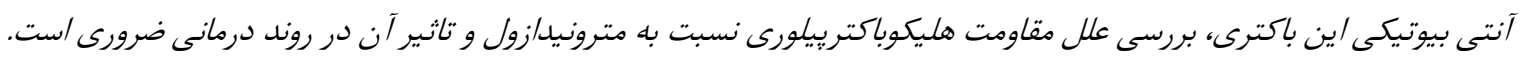

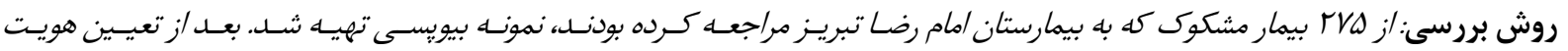

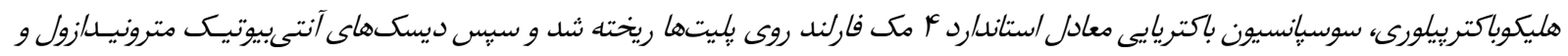

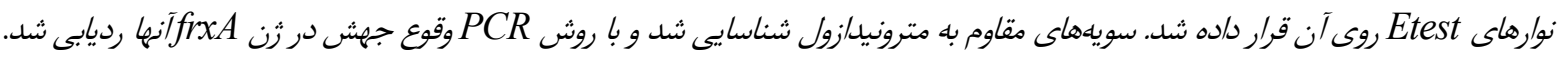

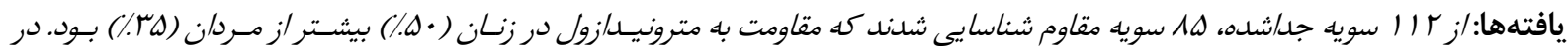

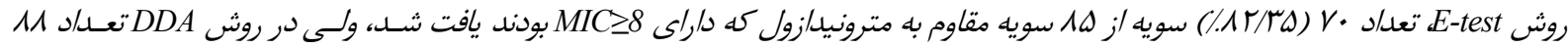

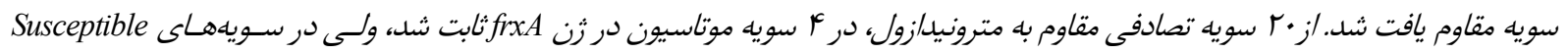
موتاسيون تثبيت نشل.

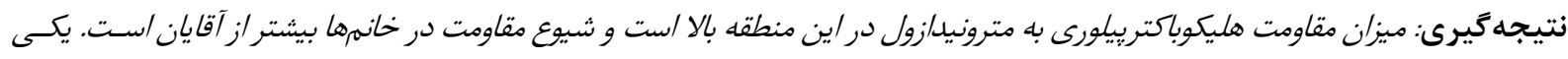

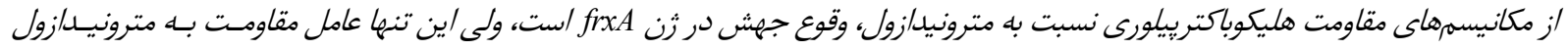

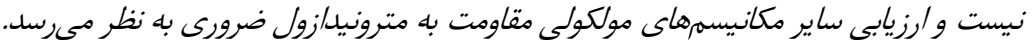

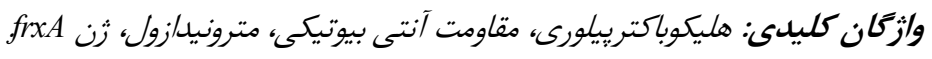

دهـانى در كشـورهاى در حـال توسـعه و از راه دهـانى -دهـانى در

مقلهمه

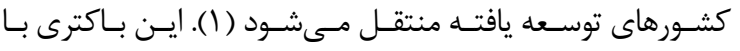

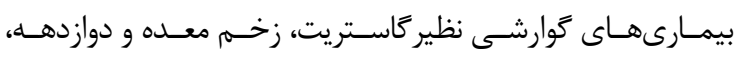

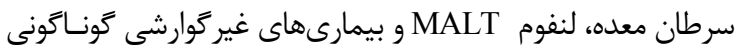

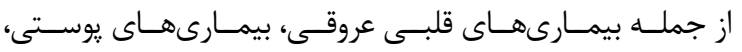

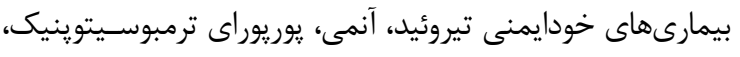

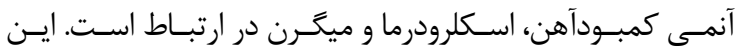

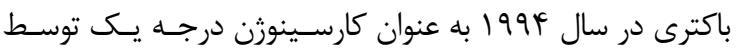

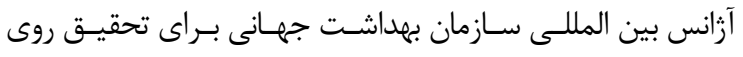
أدرس نويسنده مسئول: اليكودرز، دانشكده علوم يزشكى، واحد اليكودرز، دانشكاه آزاد اسـامى، فرشسيد

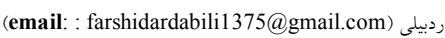
ORCID ID: 0000-0001-8058-0655 سرطان طبقه بندى شده است (Y). هليكوباكترييلورى باكترى گرم منفى، مارييجى، تازكىدار، متحرى

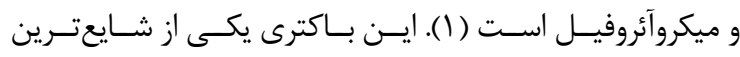

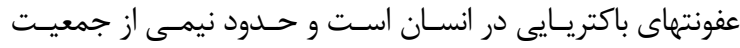

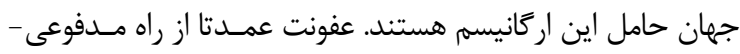
تاريخ دريافت مقاله: 


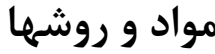

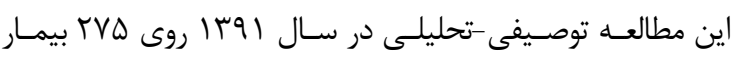

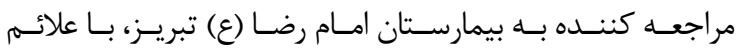

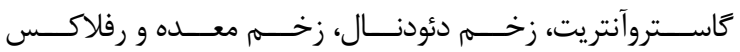

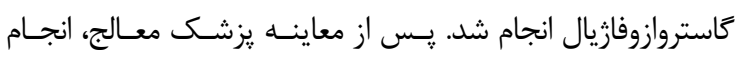

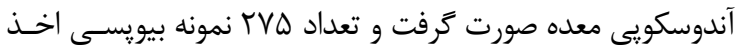

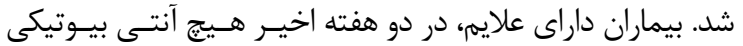

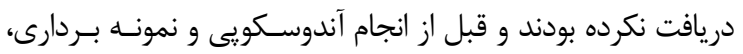
فرم رضايت توسط بيماران امضاء شد.

\section{باكترى شناسى}

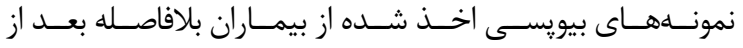

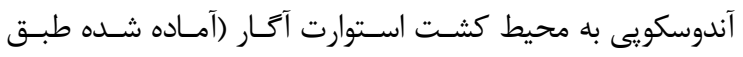

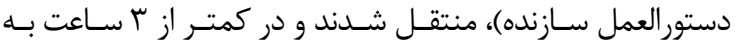

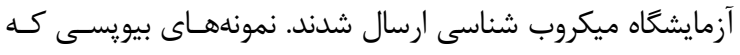

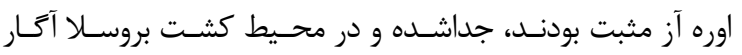

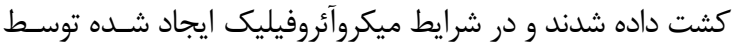

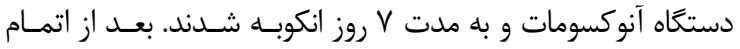

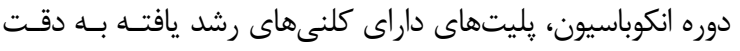

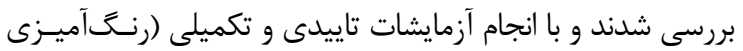

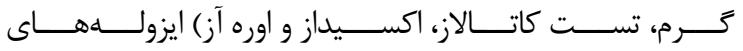
هليكوباكتر ييلورى شناسايى شدند. تعيين حساسيت آنتى بيوتيكى

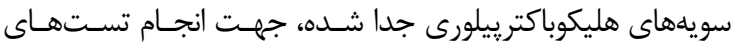

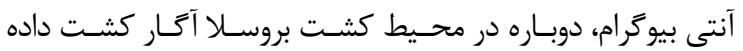

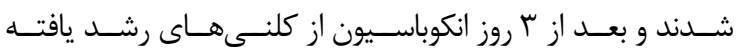

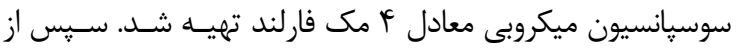
اين سوسيانسيون ميكروبى بر روى محيط كشت مولرهينتون آكار

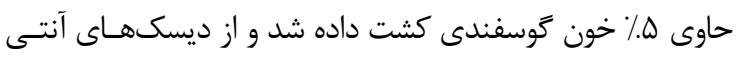

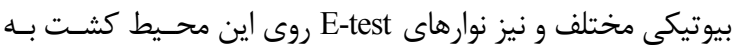
طور جداكانه قرار داده شد و بعد از ه-ب روز انكوباسيون قطر هالـه

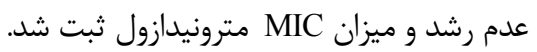

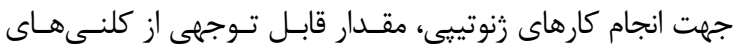
هليكوباكترييلورى رشد يافته در سطح محيط كشت را جمع كرده آنا

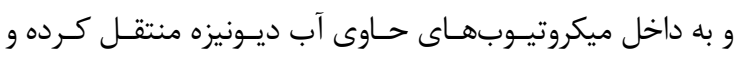

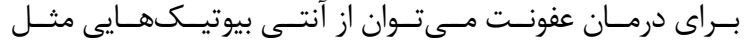

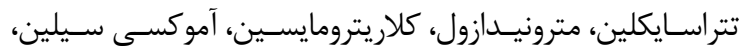

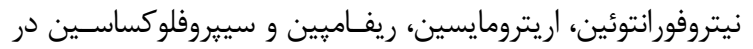

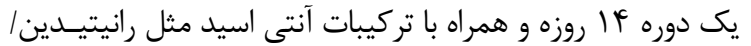

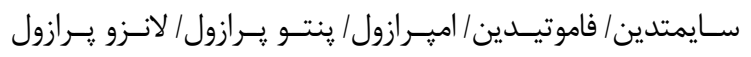

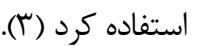
بين آنتى بيوتيكهاى ذكر شده مترونيـدازول، آموكسى سـيلين،

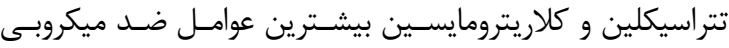

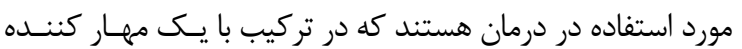

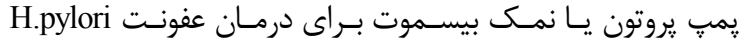

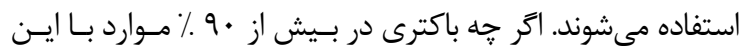

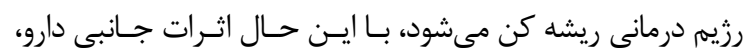

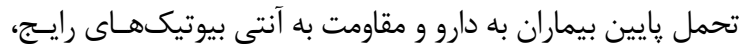

دلايل اصلى شكست درمان هستند (\&).

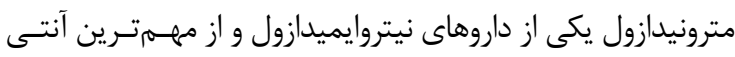

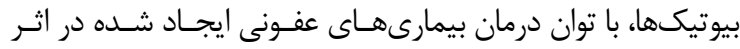

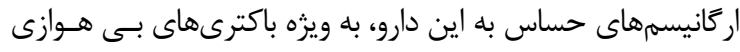

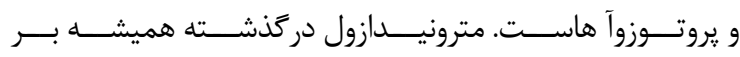

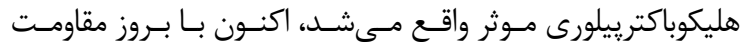

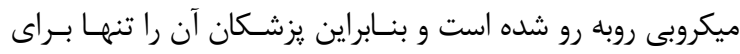

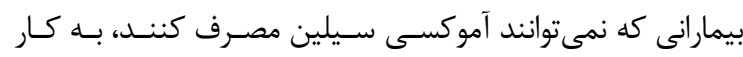

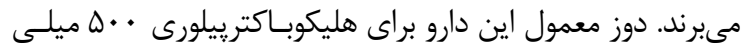
كرم و دو بار در روز است (ه).

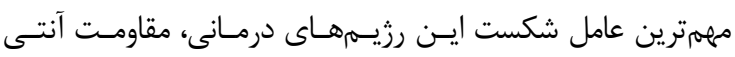

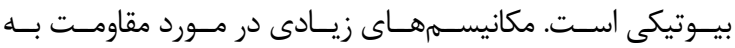

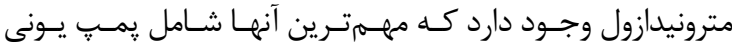

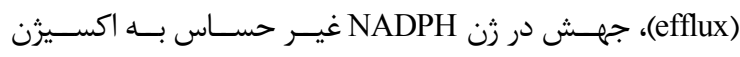

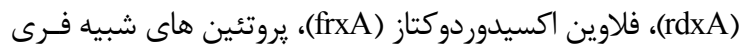

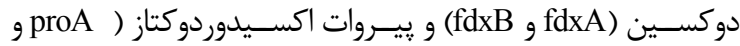

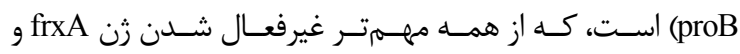
رن rdxA است (9).

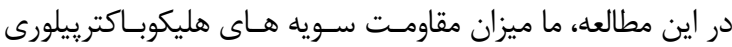

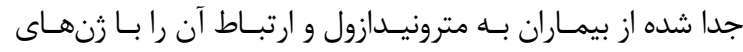
تحت بررسى قرار داديم. frxA

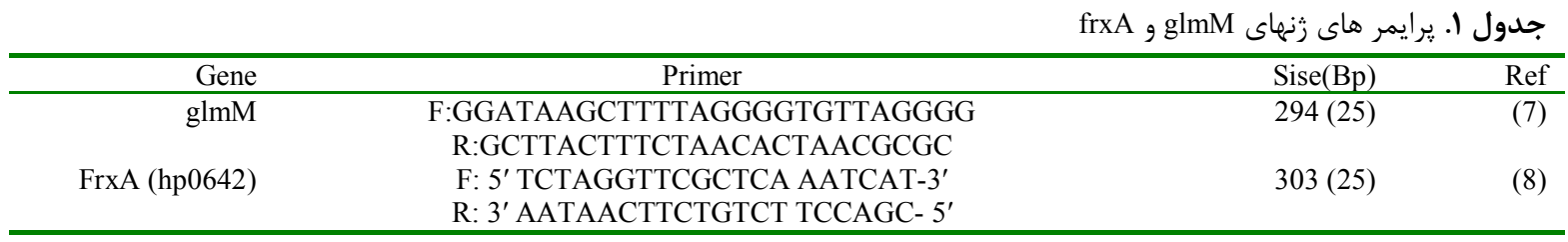




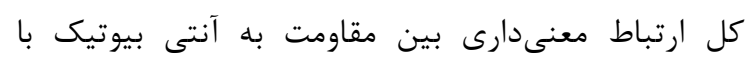

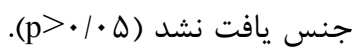

نتايج تستهاى تعيين حساسيت آنتى بيوتيكى تمام سويه-

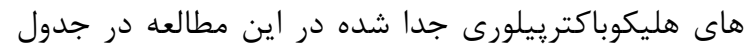

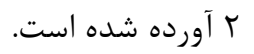
نتايج تست اوره آز و كشت در بـ 1 ٪ موارد با هم مطابقت

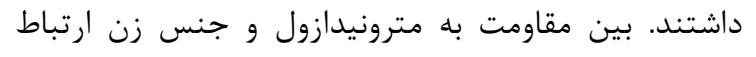

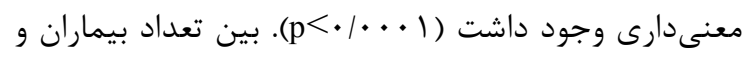

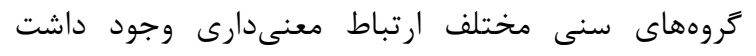

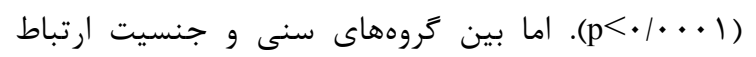

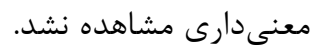
جدول r. نتايج تستهاى تعيين حساسيت آنتى بيوتيكى تمام سويههاى هليكوباكتر بيلورى جدا شدائ ندان

\begin{tabular}{|c|c|}
\hline تعداد سويه هاى مقاوم به مترونيدازول & 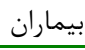 \\
\hline$(/ 49 / 11)$ ro & مرد | (مرد \\
\hline$(/ .9 \Delta / \Lambda \Lambda) \Delta \cdot$ & زن \\
\hline$(/ \wedge \Delta) \wedge \Delta$ & جمع \\
\hline
\end{tabular}

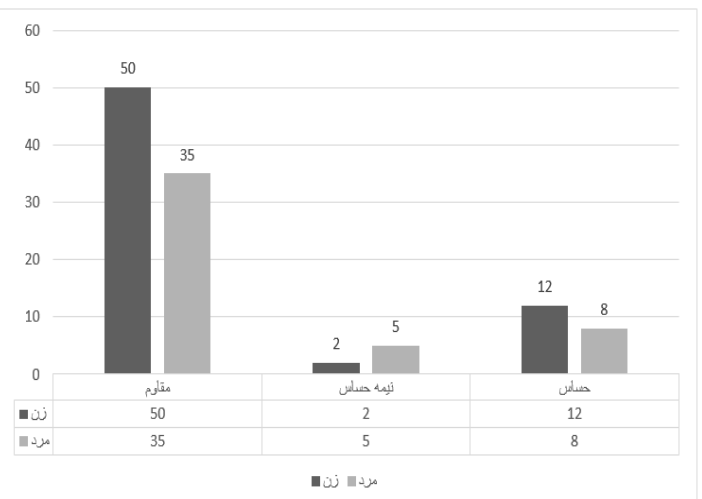

نمودار ا. مقاومت هليكوباكترييلورى به مترونيدازول به روش Eما test

كمترين غلظت مهار كنندگى مترونيدازول براى سويههاى

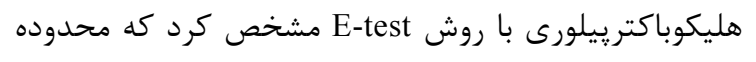

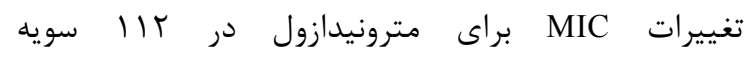
است. $19 \mu \mathrm{g} / \mathrm{ml}$

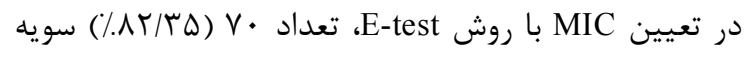
از له سويه مقاوم به مترونيدازول، داراى

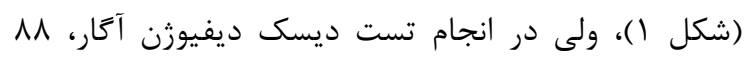

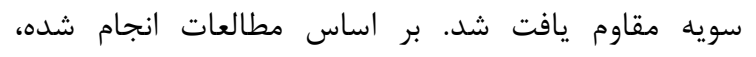
تشكيل هاله عدم رشد به قطر > 16mm براى مترونيدازول در تست MDA و DIC > ^mg/L مقاوم در نظر ترفته شد.
جهت استخراج DNA و انجام آزمايشـات زنـوتيبى در دمـاى • ·درجه سانتى كراد نكهدارى شد.

DNA استخراج عمل استخراج DNA از سويههاى جدا شده با روش Boiling و بـاــا

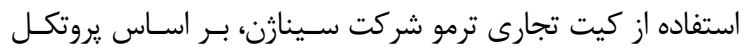

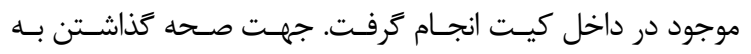

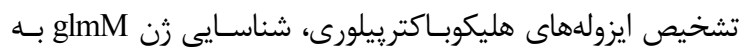

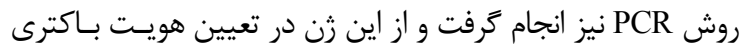

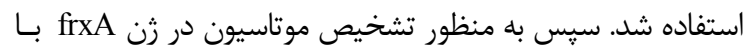
استفاده از يرايمرهاى اختصاصى PCR انجام كرفت.

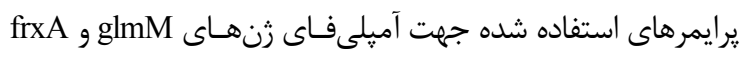

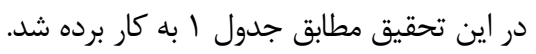

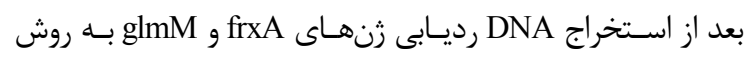
multiplex-PCR

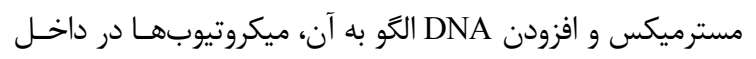

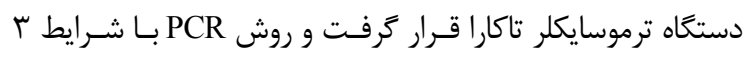

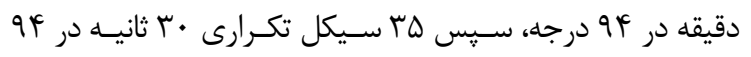

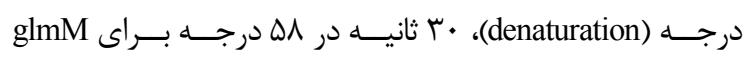

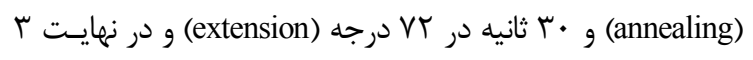

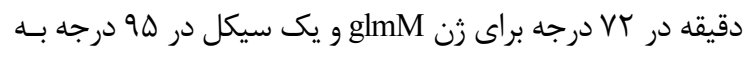

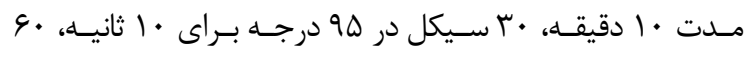

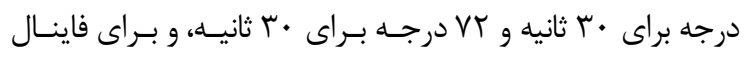

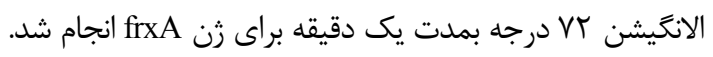

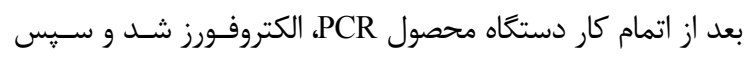

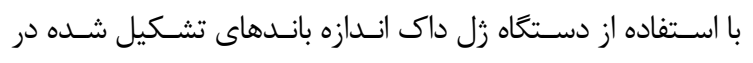
مقايسه با DNA سايز ماركر محاسبه شد.

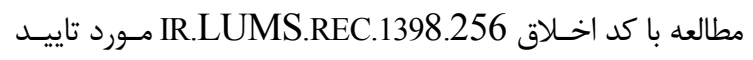

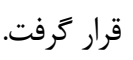

\section{يافته ها}

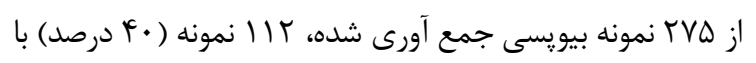

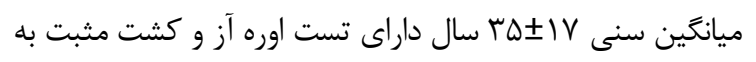

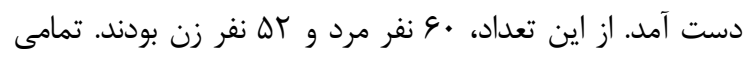

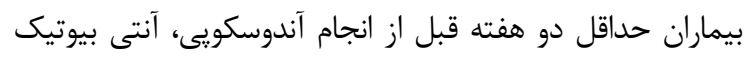

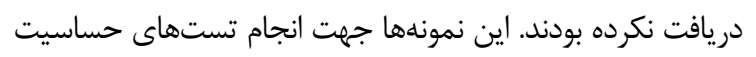
آنتى بيوتيكى و آزمايشهاى زنوتيبى وارد مطالعه شدند.

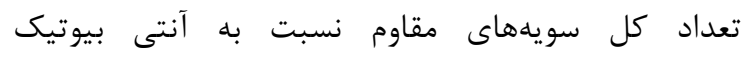

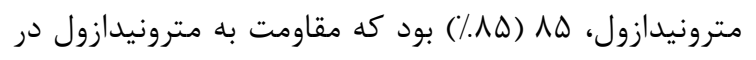

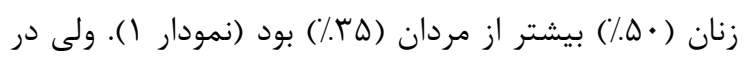


عوامل موثر بر مقاومت نسبت به مترونيدازول مهرم نيست و مهرم نقش موتاسيون است، لذا از •r مورد استفاده شد.

شكست درمان عفونتهاى هليكوباكترييلورى در تطابق با كسترش مقاومت به آنتى بيوتيكها و ضعف رزئن ريمهاى

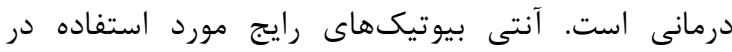
درمان اين عفونتها، مترونيدازول، كلاريترومايسين، آموكسىسيلين و تتراسايكلين هستند. در طى حندال كذشته، مقالات بسيارى از نقاط مختلف جهان مرتبط بان

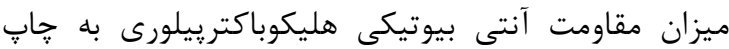
رسيده است كه مقايسه نتايج مختلف به دست آمده از آنها

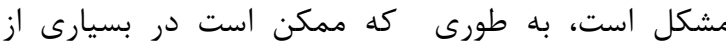
موارد، روشهاى مختلفى استفاده شده باشد. 1, rdxA و و همكارانش نقش سه زن frxA fddxA در ايجاد مقاومت به مترونيدازول در

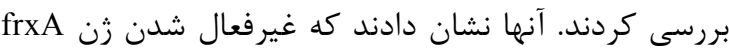

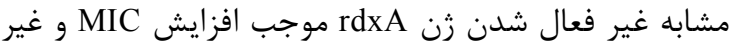

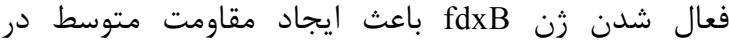

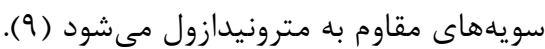

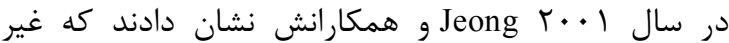
فعال شدن زن frxA موجب افزايش مقاومت بـ مانه

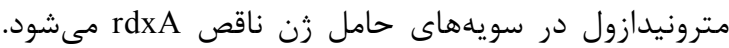

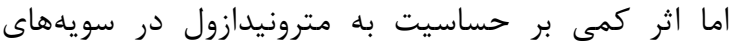

حامل آلل سالم rdxA دارد (• (1).

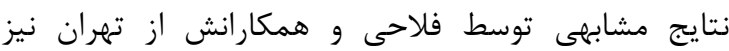
كزارش شده است كه نشان مىدهد فراوانى مقاومت به

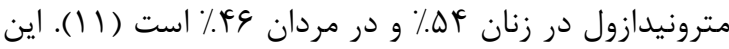

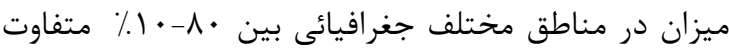

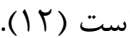

مقالات نمايه شده در سايتهاى معتبر SID و ISI نشان مىدهد كه مطالعه بر روى تعيين مقاومت هليكوباكترييلورى به به دمانه مترونيدازول در ايران مربوط به روشهاى ديسك ديفيوزن و ياليا است. در مطالعه Siavashi و همكارانش در تهران و و Savari دانشخاه تبريز، ميزان مقاومت نسبت به مترونيدازول را در

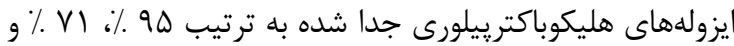

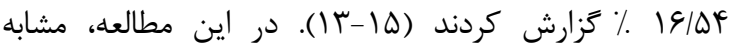
مطالعه قبلى (9)، ميزان مقاومت به مترونيدازول بالا بود

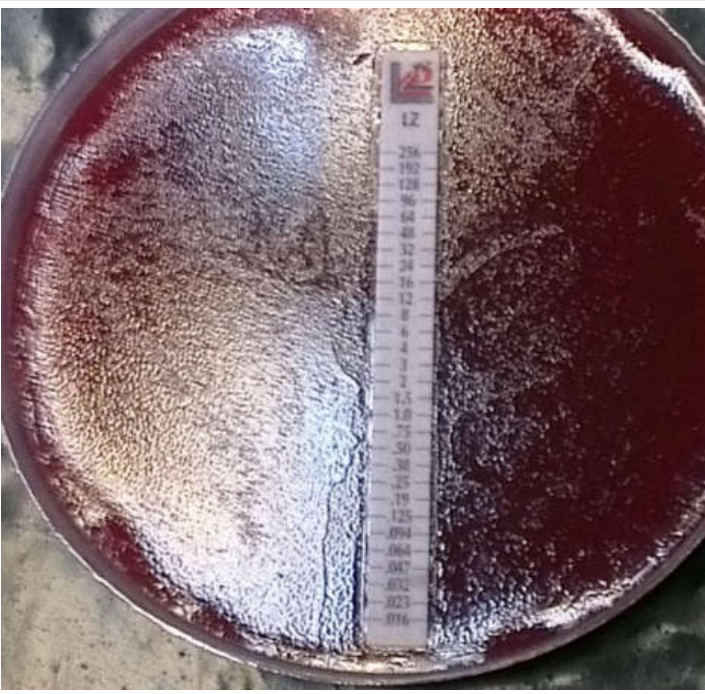

شكل ا. مقاومت به مترونيدازول با روش E-test

رديابى زن glmM در سويههاى هليكوباكترييلورى جدا شده

براى تاييد وجود DNA مربوط به هليكوباكترييلورى در

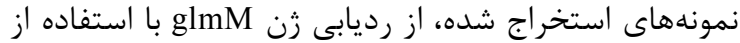

يرايمر اختصاصى اشاره شده در جدول ل استفاده شد (V)

رديابى موتاسيون در زن frxA با روش PCR از يرايمر با سايز 303bp جهت شناسايى تمامى سكانسهاى دان زن frxA (hp0642) استفاده شد. وجود موتاسيون در سكانسهاى زن frxA با سكانسهاى زن سوريه حساس

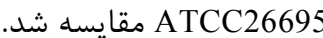

از · T سويه مقاوم (نمونهبردارى تصادفى) و • •ا سويه

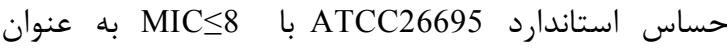
كنترل و با روش PCR انجام شد. از ·r سويه مقاوم به مترونيدازول در f أ سويه موتاسيون (Indel Mutation) در

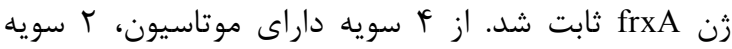

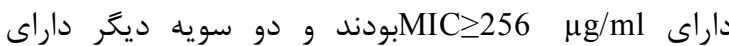
MIC=rr $\mu \mathrm{g} / \mathrm{ml}$ و MIC=q $\mu \mu \mathrm{g} / \mathrm{ml}$ Susceptible

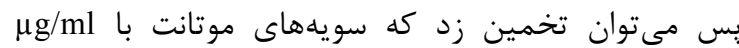
MIC $\geq 256$ يافته هاى Kown و همكارانش (9) مطابقت دارد. البته اين

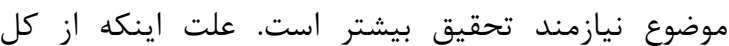
سويههاى مقاوم به مترونيدازول، جهت مشخص كردن وقوع موتاسيون در زن frxA بررسى با PCR صورت نكرفت و و تصادفى بيست مورد انتخاب شد، اين است كه اين مطالعه إيدميولوزيك نيست و آمار براى ما در قسمت بررسى 


\begin{tabular}{|c|c|}
\hline & \\
\hline 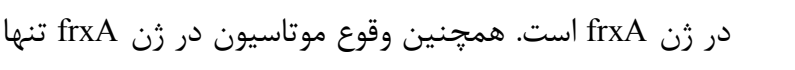 & نتايج ما حاكى از اين است كه مقاومت به مترونيدازول در \\
\hline عامل مقاومت هليكوباكترييلورى نسبت به مترونيدازول نيد & سويههاى هليكوباكتر ييلورى در بين نمونه بيويسىهاى مثبت \\
\hline و عوامل ديگرى نيز در مكانيسم مقاومت به مترونيدازول نة & هم درصد است كه اين آمار نشان مىدهد ميزان مقاومت در \\
\hline دارند. آر קه اين بحث نيازمند تحقيق بيشترى است. & بيماران مورد يزوهش بين زنان، شايعتر از مردان است كه \\
\hline در اين تحقيق، بر حسب نياز غيرفعال شدن زن frxA مد ر & احتمالا شيوع بالاى مقاومت به اين آنتى بيوتيك در كشور ما و \\
\hline بودكه روى آن بحث و تفسير انجام شد. اما ارزيابى س & برخى ديكراز كشورهاى آسيايى به علت مصرف زياد اين دارو \\
\hline مكانيسم هاى مقاومت مانند بيان بيش از . & عفونتهاى زنيكولوزيك در زنان است و جايكزينى \\
\hline RecA ،rdxA و بررسى جهش در ساير زنها از جمله RecA & ماى درمانى امرى ضرورى \\
\hline و .... در يزوهشهاى بعدى در ساير مناطق كشو & است. همجنين مطالعه ما نشان مىدهد يكى از مكانيسمهاى \\
\hline ل اله مورد يزوهش پيشنهاد مىشود. & مقاومت هليكوباكتر ييلورى نسبت به مترونيدازول وقوع جهش \\
\hline
\end{tabular}

\section{REFERENCES}

1. Gerrits MM, Berning M, Van Vliet AH, Kuipers EJ, Kusters JG. Effects of 16S rRNA gene mutations on tetracycline resistance in Helicobacter pylori. Antimicrob Agents Chemother 2003;47:2984-6.

2.Peterson WL, Fendrick AM, Cave DR, Peura DA, Garabedian-Ruffalo SM, Laine L. Helicobacter pylori-related disease: guidelines for testing and treatment. Arch Intern Med 2000;160:1285-91.

3.Chan FK, To K, Wu JC, Yung M, Leung W, Kwok T, et al. Eradication of Helicobacter pylori and risk of peptic ulcers in patients starting long-term treatment with non-steroidal anti-inflammatory drugs: a randomized trial. Lancet 2002;359:9-13.

4.Das JC, Paul N. Epidemiology and pathophysiology of Helicobacter pylori infection in children. Indian JPediatr 2007;74:287-90.

5.Tomatari FH, Mobarez AM, Amini M, Hosseini D, Abadi ATB. Helicobacter pylori resistance to metronidazole and clarithromycin in dyspeptic patients in Iran. Iran Red Crescent Med J 2010;12:409.

6.Goodwin A, Kersulyte D, Sisson G, Veldhuyzen van Zanten SJ, Berg DE, Hoffman PS. Metronidazole resistance in Helicobacter pylori is due to null mutations in a gene ( $\mathrm{rdxA}$ ) that encodes an oxygen-insensitive NADPH nitroreductase. Mol Microbiol 1998;28:383-93.

7.Dadashzadeh K, Milani M, Rahmati M, Akbarzadeh A. Real-time PCR detection of 16S rRNA novel mutations associated with Helicobacter pylori tetracycline resistance in Iran. Asian Pac J Cancer Prev 2014;15:8883-6.

8.Binh TT, Suzuki R, Trang TTH, Kwon DH, Yamaoka Y. Search for novel candidate mutations for metronidazole resistance in Helicobacter pylori using next-generation sequencing. Antimicrob Agents Chemother 2015;59:2343-8.

9.Kwon DH, Peña JA, Osato MS, Fox JG, Graham DY, Versalovic J. Frameshift mutations in rdxA and metronidazole resistance in North American Helicobacter pylori isolates. Antimicrob Agents Chemother 2000;46:793-6.

10.Jeong J-Y, Mukhopadhyay AK, Akada JK, Dailidiene D, Hoffman PS, Berg DE. Roles of FrxA and RdxA Nitroreductases of Helicobacter pylori in Susceptibility and Resistance to Metronidazole. J Bacteriol 2001;183:515562.

11.Fallahi G-H, Maleknejad S. Helicobacter pylori culture and antimicrobial resistance in Iran. Indian J Pediatr 2007;74:127.

12.Kim JJ, Reddy R, Lee M, Kim JG, El-Zaatari FA, Osato MS, et al. Analysis of metronidazole, clarithromycin and tetracycline resistance of Helicobacter pylori isolates from Korea. Antimicrob Agents Chemother 2001;47:459-61.

13.Rafeey M, Ghotaslou R, Nikvash S, Hafez AA. Primary resistance in Helicobacter pylori isolated in children from Iran. J Infect Chemother 2007;13:291-5.

14.Siavashi F, Safari F, Doratotaj D, Khatami Gr, Falahi Gh, Mirnaseri S. Antimicrobial resistance of Helicobacter pylori isolates from Iranian adults and children. Arch Iran Med. 2006;9:308-14.

15.Abdollahi H, Savari M, Zahedi MJ, Darvish Moghadam S, Hayatbakhsh Abasi M. A study of rdxA gene in metronidazole resistant and sensitive Helicobacter pylori isolates in Kerman, Iran. Jundishapur J Microbiol. 2011; 4(2): 99-104.

16.Milani M, Ghotaslou R, Somi MH, Rafeey M, Akhi MT, Nahaei MR, et al. The status of antimicrobial resistance of Helicobacter pylori in Eastern Azerbaijan, Iran: comparative study according to demographics. J Infect Chemother. 2012;18:848-52. 